\title{
QUEEN'S
UNIVERSITY
BELFAST
}

\section{Change and Continuity Across the 9/11 Fault-Line: Rethinking Twenty-First-Century Responses to Terrorism}

English, R. (2019). Change and Continuity Across the 9/11 Fault-Line: Rethinking Twenty-First-Century Responses to Terrorism. Critical Studies on Terrorism, 12(1), 78-88.

https://doi.org/10.1080/17539153.2018.1494119

Published in:

Critical Studies on Terrorism

Document Version:

Peer reviewed version

Queen's University Belfast - Research Portal:

Link to publication record in Queen's University Belfast Research Portal

Publisher rights

(c) 2018 Taylor \& Francis.

This work is made available online in accordance with the publisher's policies. Please refer to any applicable terms of use of the publisher.

\section{General rights}

Copyright for the publications made accessible via the Queen's University Belfast Research Portal is retained by the author(s) and / or other copyright owners and it is a condition of accessing these publications that users recognise and abide by the legal requirements associated with these rights.

Take down policy

The Research Portal is Queen's institutional repository that provides access to Queen's research output. Every effort has been made to ensure that content in the Research Portal does not infringe any person's rights, or applicable UK laws. If you discover content in the Research Portal that you believe breaches copyright or violates any law, please contact openaccess@qub.ac.uk. 
Change and Continuity Across the 9/11 Fault Line: Rethinking Twenty-FirstCentury Responses to Terrorism

\section{Richard English}

(Queen's University Belfast)

Professor Richard English, Queen's University Belfast, r.english@qub.ac.uk, 02890973131 (Vice-Chancellor's Office, University Road, Queen's University, Belfast BT7 1NN) 


\begin{abstract}
This article asks the following questions. Which terrorism threats, challenges and responses did key players consider to have been decisively changed by $9 / 11$ ? On close inspection now, nearly two decades after those attacks, how are we to assess such claims? What did 9/11 really change regarding terrorism and counter-terrorism? And what remained unaltered? The article's central argument is this: some western states exaggerated the extent to which terrorist threats and challenges had been changed by $9 / 11$ and, as a consequence, they did significantly alter some of their responses to terrorism; but at the heart of this ironic process was the tragic reality that, had there been a more serious-minded and historically sensitive recognition of how little had necessarily been changed by $9 / 11$ in terms of terrorist threats and challenges, then the twenty-first-century experience of non-state terrorism would have been much less painful than has been the case in practice.
\end{abstract}

\title{
Keywords
}

Terrorism; counter-terrorism; 9/11 
What was claimed to have changed after $9 / 11$ ?

In Washington and London, certainly, there was a decision by some key policymakers to read 9/11 as having changed the world decisively. The September 11 attackers were presented as having embodied an utterly new kind of foe: the terrorist threat had been transformed, so the argument ran, and this new set of challenges demanded a very new set of responses.

Let us look again at some of the claims that were actually made. President George W. Bush (17 September 2001): "I know that this is a different type of enemy than we're used to. It's an enemy that likes to hide and burrow in, and their network is extensive. There are no rules. It's barbaric behaviour. ... And we're adjusting our thinking to the new type of enemy"; Alberto Gonzalez (White House Counsel 2001-5 and US Attorney General 2005-7): "the war against terrorism is a new kind of war"; Condoleezza Rice (US National Security Advisor 2001-5 and Secretary of State 20059): 9/11 'changed the way we view foreign policy'; CIA Director George Tenet's view, expressed on 16 September 2001: "all of the rules have changed"; in the words of Cofer Black (Director of the CIA's Counter-Terrorist Center 1999-2002), "there was before 9/11 and after 9/11. After 9/11 the gloves came off' (Arsenault 2017, 14, $85,126,129,167)$. 
Nor was it merely a US-phenomenon. In the words of former UK Prime Minister Tony Blair, 9/11 was "an event like no other ... a world-changing one”; "It was war. ... But it was a war unlike any other. ... This mass terrorism is the new evil in our world. ... We, therefore, here in Britain stand shoulder to shoulder with our American friends in this hour of tragedy, and we, like them, will not rest until this evil is driven from our world" (Blair 2010, 342, 345, 352).

We need to recall, of course, the merciless violence that was involved in $9 / 11$, the nearly three thousand victims who were killed, the psychological and political shock that the attack generated, the economic damage that it did, the fact that it remains by far the most lethal act of non-state terrorism in history, and the reality that - at the point of immediate reaction - policy-makers had far from perfect knowledge about how sustained a threat such jihadist violence might now pose. So I do not want to dismiss at all casually the enormity of the problem that was presented to leaders in Washington, London and elsewhere by this blood-stained assault.

Even so, and even at the time, the scale of what was claimed to be involved in $9 / 11$ was, for some key western policy-makers, arguably still markedly extreme. In one recent scholar's apt phrasing: in the USA, at least, such "policy makers saw 9/11 as ... a paradigm-changing event that required the United States to wage a new kind of war, one that required new rules and methods for victory" (Arsenault 2017, 16). Such methods were to include major military campaigns abroad, vast new spending on homeland security in the US and on domestic counter-terrorism in other western 
countries, an altered view of what was legitimate in terms of the treatment of terrorism suspects, some significantly changed legal frameworks, and a new prioritisation of the threat and challenge that were posed by non-state terrorists.

\section{II}

But what did 9/11 really change in terms of terrorism threats, challenges and responses?

The central argument of this article is as follows: some western states exaggerated the extent to which terrorist threats and challenges had been changed by $9 / 11$ and, as a consequence, they did significantly alter some of their responses to terrorism; but at the heart of this ironic process was the tragic reality that, had there been a more serious-minded and historically sensitive evaluation of how little had necessarily been changed by $9 / 11$ in terms of terrorist threats and challenges, then the twenty-firstcentury experience of non-state terrorism would have been much less painful than has been the case in practice. A misreading of what $9 / 11$ had altered in terms of threats and challenges, therefore, led to an avoidable and counter-productive set of changes in terms of counter-terrorist state response. 
Let us examine first some of the changed state responses and then we can consider the actual, historical continuities that existed across the supposed 9/11 fault line, and can reflect on some of their significant implications.

There certainly was in some western states a post-9/11 legitimation of new modes of counter-terrorism. As one senior Bush administration official bluntly put it in October 2001, "Lethal operations that were unthinkable pre-September 11 are now underway" (Arsenault 2017, 14). The United States and some of its allies did alter what they saw as being legitimate in the treatment of detainees who were suspected of terrorism, and this allowed for some outrageous acts (whether in Abu Ghraib, in Guantanamo, or in a series of disreputable black sites). Some distinguished figures made footnoted cases for a new approach to torture (Dershowitz 2002); the US Central Intelligence Agency and Department of Defense both oversaw the torture of detainees; and the USA also transferred suspects to third-party countries for dark modes of questioning. It is fair to suggest that these changes represented something of a degradation of the normal and aspirational values embodied in states such as the USA and UK (Gearty 2013).

Part of this involved a new prioritisation of terrorism at the highest levels of, certainly, US politics. (It is important not to forget how trivial terrorism was considered by the White House on 10 September 2001.) This reprioritisation, and the processes of degradation to which I have referred, had war-time dimensions too. For there was a contingent choice taken, most significantly (but not uniquely) by the United States of America, to see $9 / 11$ as a partial justification for a war in Iraq, as 
well as for the more obvious and earlier conflict in Afghanistan. These choices did man that "After 9/11" has become a not completely unjustified periodisation of human history (for all of the problems that any such periodization involves). The 9/11 wars did help to recast international relations as well as the US foreign policy which so powerfully defines them (Burke 2011). The jagged and complex journey from al-Qaida, through 9/11, to the war in Iraq, to al-Qaida in Iraq and its transformation into ISIS - is one which has generated much conflict and some nontrivial recasting of regional and international politics (Byman 2015; Cockburn 2014; Stern and Berger 2015; Gerges 2016; McCants 2015; Weiss and Hassan 2015).

These changes were genuine and they were significant. Ironically, they helped to generate a notable increase in fatalities from non-state terrorism, and in the number of non-state terrorist attacks, during the high phase of a war on terror which was ostensibly intended to rid the world of terrorism (English, Does Terrorism Work?, 2016, 4); unintended consequences abound in the interaction of terrorism and counter-terrorism throughout history. There were also significant (and not unrelated) shifts in domestic contexts within the west, including some alterations in the relationship between Muslim and non-Muslim inhabitants of western democracies (Croft 2012; Warsi 2017).

Less politically momentous, but again far from trivial, was the effect of $9 / 11$ on academic scholarship. One gloriously unintended consequence of al-Qaida's brutal attack in 2001 was the dual one of unprecedentedly expanding the amount of academic attention subsequently devoted to the study of terrorism and (even more ironically) of effectively Americanising the study of non-state terror. Prior to 9/11, 
the academic study of terrorism was something of a pagan religion; after it, such endeavours became a mainstream faith. There is unquestionably far more now being published on the subject of terrorism than had been the case before 9/11 (Silke 2007, 78-9; Ranstorp 2009, 22); and the transformation of this process has been most notable and most influential in the USA. This has had some important effects, intellectually and also in terms of policy. The post-9/11 focus in the US has been explicably, emphatically, and yet surely disproportionately focused on jihadist, antiAmerican terrorism; and the methodological centre of gravity (very often now quantitative) has had a disciplinary set of consequences (one of which has been something of a hardening of the intellectual border between the US and some other parts of the western world) (English, 'Future Study', 2016).

III

What has not changed, despite $9 / 11$ ?

The above changes in response emerged from an exaggeration of the degree to which 9/11 actually, necessarily brought about a change in terrorist threats and challenges. Even allowing for the aforementioned rise in terrorist attacks and terrorist-generated fatalities after 2001 (yet more proof of the mutually shaping relationship that exists between non-state terrorists and their state enemies (English 2015), the reality is that the broad threat from non-state terrorism has not risen to the levels that some policymakers expected, and that many have presented to be the case. 
For example, writing very much within the post-9/11 era, and attending to detailed data, Richard Jackson and colleagues rightly point out that "rigorous assessment of the relevant statistical evidence and past terrorist behaviour shows that terrorism ranks extremely low as a threat to human life and well-being. The available evidence suggests that, outside warzones, those seeking to perpetrate terrorist attacks are few in number and mostly lacking in the necessary capabilities" (Jackson et al 2011, 139). This is in no way to dismiss the appalling suffering that victims of non-state terrorism experience (Argomaniz and Lynch 2015). But it is important to be clear about the actual proportions of terrorist threats and challenges.

It is worth noting in relation to the threat in the USA, therefore, that (as John Mueller and Mark Stewart point out), "scarcely any al-Qaida operatives have ever been unearthed in the United States"; that "the objective probability that an American will be killed by a terrorist in the United States, with the events of 2001 very much included in the count, stands at about one in 4 million per year. If one concentrates just on the period since 2001," they continue, "it is about one in 110 million each year" (Mueller and Stewart 2016, 1, 67).

Nor, despite the amnesiac panic that so frequently emerges in the media when a terrorist attack now occurs in the west, should we ignore just how longstanding some form of terrorist threat has been. It is not merely that there were enduring westEuropean campaigns of terrorist violence which contextually dwarfed the current 
jihadist challenge to western democracies (though this is true and important) (English 2012; Whitfield 2014); it is also the case that, in the US itself, there has actually been a long experience of facing a persistent terrorist challenge. During 1971 and 1972, for example, the FBI recorded on average more than three domestic terrorist bombings per day in the United States (Hamm and Spaaij 2017, 42).

After 9/11, therefore, what we have too often seen is an exaggeration of the terrorist challenge. In Marc Sageman's words, there has been “a great inflation of the terrorist threat to the United States, resulting in popular hysteria that leads to calls to abrogate civil liberties of suspect populations and demands to kill hundreds or thousands of innocent Muslims abroad". In relation to jihadist terrorism specifically, he continues: "The global neojihad poses a threat to the United States and the west, but it does not rise to a level where it threatens their existence. To put this threat in context, car accidents and US firearm homicides pose threats to western and US lives several orders of magnitude higher than does the global neojihad" (Sageman 2017, 21, 58). "Over-responding to rare events", as other recent authors have phrased it, represents a familiar problem in counter-terrorism; indeed, "producing over-reaction by governments is often a major goal of those using terrorist tactics" (Crenshaw and LaFree 2017, 33-4).

It is not, of course, that nothing changed with or after $9 / 11$. As in all previous periods of terrorist history, there were some new developments, each organisational campaign having its own unique features as well as some family resemblances with prior cases. Clearly, the shockingly new scale of the $9 / 11$ attack itself altered the range of fears in 
Washington (and elsewhere) about what non-state terrorists might now plan and might now achieve. And the post-9/11 terrorist world did contain some importantly new features: al-Qaida after 9/11 evolved (partly in reaction to state counter-terrorist policies) and, not unrelatedly, ISIS emerged as a terrorist actor with quasi-state pretensions and significant international magnetism (English, Does Terrorism Work?, 2016, 42-91, 246).

But these were incremental developments rather than discretely pre- and post-9/11 worlds. In that sense, the phrase "After 9/11" ultimately suggests too neat a periodisation of history. 11 September formed part of a very long sequence of acts of jihadist political violence (Williams 2017) and, while some elements of this were new, many were not. So, for example, the much-discussed phenomenon of post-2001 lone actor terrorism comprises some shifts, but also much continuity, across the supposed 9/11 fault line (Hamm and Spaaij 2017).

Indeed, many aspects of supposedly new, post-9/11 forms or structures of terrorism turn out, on close investigation, to be less novel than is sometimes claimed (Bourne 2014, 232, 247; English, Does Terrorism Work? , 2016, 12, 50, 281); certainly, much that has become noted with regard to post-9/11 jihadist fellow-travellers (including the phenomenon of disoriented people with low-grade criminal pasts, seeking redemptive apotheosis through terrorist violence that is carried out in an ostensibly noble and international cause), is actually very familiar to anyone who is wellacquainted with the long history of terrorism (Toobin 2017, 1-2, 26-7, 31-2). 
Much more profoundly, the context which generates non-state terrorism has been unfolding and interwoven over incrementally advancing years, rather than decisively altered by one blood-stained event in September 2001. Serious-minded readings of the Middle East suggest that deep-rooted and complex continuities and inheritances across 2001 are more important in the region than are any new realities generated by the 9/11 attack (Gelvin 2016). Even some of what was arguably new in contextual terms - for example, the influential neoconservative engagement that was reflected in the Iraq adventure - soon lost momentum and credibility, and has failed to endure in subsequent US Presidential regimes.

In terms of analysis, again it is the echoes of pre-9/11 worlds that are often very notable. Some of what is now presented as a novel way of understanding terrorism is, in fact, very familiar indeed. So Marc Sageman's 2017 adumbration of a supposedly new "model of the turn to political violence" sets out an explanation that would be deeply familiar already to anyone who had studied pre-9/11 non-state terrorism: "the activation of a politicised social identity, which generates an imagined political protest community"; "escalation of hostility between the state and their community, which includes a cumulative radicalisation of discourse"; "disillusionment with nonviolent legal tactics"; and "moral outrage at new state aggression against their community" (Sageman 2017, 111, 117, 130). 
The most important continuity of all, however, is this: at the heart of the "After 9/11" debate is the depressing reality that we knew, long before 2001 , the best ways to respond effectively to terrorism; and yet western states deviated damagingly from such behaviour in the wake of the al-Qaida atrocity against America. As so often, therefore, it has been how states contingently respond to terrorism, rather than terrorism itself, which has most decisively changed history and politics.

One especially painful aspect of this relates to torture. It had long been known that torture did not represent an effective way of generating reliable evidence. For example, one of the CIA's own documents from 1958 (entitled "The Interrogation of Suspects Under Arrest") makes admirably clear that:

The question of torture should be disposed of at once. Quite apart from moral and legal considerations, physical torture or extreme mental torture is not an expedient device. Maltreating the subject is from a strictly practical point of view as short-sighted as whipping a horse to his knees before a thirty-mile ride. It is true that almost anyone will eventually talk when subjected to enough physical pressures, but the information obtained in this way is likely to be of little intelligence value and the subject himself rendered unfit for further exploitation (Arsenault 2017, 155).

Reinforcing such assessments is a now vast body of careful argument, by scholars and by people with interrogation and counter-terrorist experience, to the effect that torture 
is an ineffective method for obtaining the information that it purportedly seeks (O’Mara 2015; Schiemann 2016; Matchett 2016). So the fact that torture has proven counter-productive within counter-terrorism (Arsenault 2017, 168-79) should have come as no surprise, and the process of again discovering that reality could have been avoided.

This fits a wider pattern. I have argued elsewhere that, based on close attention to the long history of terrorism and counter-terrorism, there exist a series of crucial principles which lie at the heart of successful responses to terrorist threats and challenges: learn to live with terrorism, rather than pretending that it can be eradicated; where possible, address the underlying root problems and causes which generate non-state terrorist violence; avoid an over-militarisation of response; recognise the vital fact that high-grade intelligence is the most crucial element in successful counter-terrorism; respect (rather than abandon) orthodox legal frameworks, and adhere to the democratically-established rule of law; ensure the effective coordination of security-related, financial and technological preventative measures, whether within states, or between states who share a terrorist opponent; and maintain strong credibility in counter-terrorist public argument (English 2009, 11843). Such arguments resonate with the views of many people with longstanding expertise in the field (Richardson 2006; Roberts 2015); they are based on a close reading of much historical and political experience, and on evidence which was available in 2001; and yet all of these principles were significantly and damagingly ignored during the post-9/11 War on Terror. 
So there were indeed what might be termed "knowns knowns". But, sadly, these were substantially ignored by many people who wielded policy influence. It is not that there were no wise voices in governmental and policy circles, nor that no good work was done to combat non-state terrorism and the threats and challenges that it embodies (Omand 2010). But even after the war on terror's high phase, some aspects of the counter-terrorist framework set out above have been absent from major policy pronouncements and interventions. So, for all of the seeming demands for public rhetoric, I still think that President Trump's Inaugural Speech declaration - "we will eradicate [radical Islamic terrorism] completely from the face of the earth" (20 January 2017) - sets the bar of expectation far too high, suggesting as it does a capacity for eradicating something which is more feasibly only to be contained. One of the areas of success open to terrorists is the maintenance of resistance in the face of state hostility (English, Does Terrorism Work?, 2016). To state publicly that you are going to achieve things in counter-terrorism which are simply not achievable gives another gift to your terrorist adversaries. This should be avoided.

My point is not that counter-terrorism is easy. Of course it is not. But historically clear-sighted analysis made clear from early on both that the level of threat from terrorism had not, in most ways, dramatically been altered by $9 / 11$ (as Eric Hobsbawm clearly articulated it over a decade ago, "The actual danger of the new international terrorist networks to the regimes of stable states in the developed world ... remains negligible" (Hobsbawm 2007, 135)), but also that the basis for our most effective responses to terrorism has remained consistent across that supposed 2001 fault line in history. 
Reinforcing the point that we should not exaggerate the plausibility of an "After 9/11" era is the further fact that, despite the things that have changed in terms of counterterrorist methods, much even here has in practice remained familiar and consistent, post-9/11 as before.

So, even in terms of US and UK responses to terrorism, much was not lastingly changed after 11 September. Despite some people's best efforts, there did not emerge a lastingly new norm legitimising torture; and anyway there had (under the prior US norm that torture was essentially to be avoided) in fact been much torture by the USA in practice in any case. Water-boarding was and is atrocious; but its post-9/11 deployment neither represented an enduringly new public orthodoxy nor, regrettably, an entirely new venture in US responses to its enemies. The fact that some American policy-makers attempted to change enduringly the norms surrounding the USA's use of torture was arguably, in itself, less significant a shift than some have claimed. If you are being tortured, with a CIA operative present in the cell, then the issue of whether or not this contravenes official and public US policy for the treatment of detainees is arguably less important than that fact that you are (as happened disgracefully during the Cold War earlier) being tortured with the complicity of the United States of America. In any case, the most detailed study to date of this subject has judged that the norm regarding torture was ultimately not lastingly changed as a response to 9/11, despite some actors' desire that it should be (Arsenault 2017). 
Similarly, the extension of executive powers within the USA after 9/11 was far from unprecedented in the western world, where the post-terrorist extension of powers has been something of a recurring pattern (Donohue 2008). Again, the US state repeatedly lied during the justification for, and the practice of, the post-9/11 War on Terror (Williams 2017, 97-168); but for US Presidents and their comrades to lie about military and other significant matters is hardly an innovation, as the recent National Security Advisor H. R. McMaster has shown in his own superb study of the Vietnam War (McMaster 1997, 51, 54, 57, 74, 78). Yet again, the continuities of US experience in dealing with Israel/Palestine (and with the terrorism that occurs there) are very striking, across the supposed fault line of 2001 (Kurtzer et al 2013).

IV

What conclusions can be drawn from all this?

As hinted, there is a well-established recognition within the academic literature that countering terrorism is far from easy (Crenshaw and LaFree 2017; McConaghy 2017, 160). But the long history of terrorism and counter-terrorism did provide people with a basis - even in 2001 itself, and certainly in subsequent years - for understanding more clearly the true proportions of the terrorist threat and challenge involved, and for responding in a more measured and effective and life-saving manner than states so often did during the past seventeen years. 
The irony here is that a sharper sense of how little had changed in terms of the threat and the challenge, and how little therefore needed to change in terms of counterterrorist response, would have limited the damage done (and the success achieved) by non-state terrorists, and would have made the already strong continuities between preand post-9/11 even more pronounced. Those aspects of the 9/11 effect which most significantly do embody a change occasioned by that atrocity, tend to have been those that were based on their progenitors' contingent exaggeration of the novelty and significance of the 2001 attacks. It was because policy-makers and influencers in Washington and London misread what had happened (and what could now happen) that 9/11 had some of its most momentous and most avoidable consequences.

Several points here shout out clearly to historians (conscious as we are of contingency and long-term time-frames) (English, Does Terrorism Work?, 2016, 17-30), but they are surely also equally striking to those whose expertise grows from different disciplinary specialisms. The processes described in this paper were contingent rather than inevitable: there were counter-terrorist, non-neutral (Stohl 2008) choices made in Washington, in London, in Langley, in Quantico, in Thames House, in Vauxhall, and elsewhere, which involved real opportunities for a different, more measured, more proportionate, and surely more effective response to non-state terrorism after 9/11. Similarly, benign (or malign) and proportionate (or exaggerated) options exist now and in the largely unpredictable years of counter-terrorism ahead. 
Careful reflection on historiography cautions against seeing history as a predictive science (Evans, 1997). But reflection on long pasts can, despite this, possess a public and policy-relevant dimension of genuine importance (Guldi and Armitage 2014). And, if read according to long historical pasts - rather than according to short-term, amnesiac frameworks - then what occurred on that shocking Tuesday in 2001 seemed and seems far less new than those who want us to think that the world changed with 9/11 have disastrously tried to persuade us. Much less changed on 11 September 2001 than many leaders and influential pundits claimed; continuities were more significant than fractures; and even those changes which did occur grew mostly out of distorted exaggerations. So is there an "After After 9/11"? Yes: in complex ways we have been living there all along.

\section{Acknowledgements}

This article emerged from a paper delivered in January 2018 at the University of California Santa Barbara (UCSB) Workshop "Is There an After After 9/11: Terrorism Threats, Challenges, Responses". I am grateful to Professor Michael Stohl for organising the Workshop and inviting me to speak at it, and to all of the participants for their valuable insights at the event. 


\section{References}

Argomaniz, Javier and Lynch, Orla, eds. 2015. Victims of Terrorism: A Comparative and Interdisciplinary Study. London: Routledge.

Arsenault, E. G. 2017. How the Gloves Came Off: Lawyers, Policy Makers and Norms in the Debate on Torture. New York: Columbia University Press.

Blair, Tony. 2010. A Journey. London: Hutchinson.

Bourne, Michael. 2014. Understanding Security. Basingstoke: Palgrave Macmillan.

Burke, Jason. 2011. The 9/11 Wars. London: Penguin.

Byman, Daniel. 2015. Al-Qaida, The Islamic State and the Global Jihadist Movement: What Everyone Needs to Know. Oxford: Oxford University Press.

Cockburn, Patrick. 2014. The Jihadis Return: ISIS and the New Sunni Uprising. New York: Or Books.

Crenshaw, Martha and LaFree, Gary. 2017. Countering Terrorism. Washington: Brookings Institution Press.

Croft, Stuart. 2012. Securitizing Islam: Identity and the Search for Security. Cambridge: Cambridge University Press.

Dershowitz, A. M. 2002. Why Terrorism Works: Understanding the Threat, Responding to the Challenge. New Haven: Yale University Press.

Donohue, L. K. 2008. The Cost of Counter-Terrorism: Power, Politics, and Liberty. Cambridge: Cambridge University Press.

English, Richard. 2009. Terrorism: How to Respond. Oxford: Oxford University Press. 
English, Richard. 2012. Armed Struggle: The History of the IRA. $3^{\text {rd }}$ ed. London: Pan Macmillan.

English, Richard, ed. 2015. Illusions of Terrorism and Counter-Terrorism. Oxford: Oxford University Press.

English, Richard. 2016. Does Terrorism Work? A History. Oxford: Oxford University Press.

English, Richard. 2016. "The Future Study of Terrorism." European Journal of International Security 1 (2): 135-49. doi:10.1017/eis.2016.6.

Evans, R. J. 1997. In Defence of History. London: Granta.

Gearty, Conor. 2013. Liberty and Security. Cambridge: Polity Press.

Gelvin, J. L. 2016. The Modern Middle East: A History. Oxford: Oxford University Press.

Gerges, F. A. 2016. ISIS: A History. Princeton: Princeton University Press.

Guldi, Jo and Armitage, David. 2014. The History Manifesto. Cambridge: Cambridge University Press.

Hamm, M. S. and Spaaij, Ramon. 2017. The Age of Lone Wolf Terrorism. New York: Columbia University Press.

Hobsbawm, Eric. 2007. Globalisation, Democracy and Terrorism. London: Little, Brown.

Jackson, Richard, Jarvis, Lee, Gunning, Jeroen and Breen Smyth, Marie. 2011. Terrorism: A Critical Introduction. Basingstoke: Palgrave Macmillan.

Kurtzer, D. C., Lasensky, S. B., Quandt, W. B., Spiegel, S. L. and Telhami, S. Z. 2013. The Peace Puzzle: America's Quest for Arab-Israeli Peace, 1989-2011. Ithaca: Cornell University Press. 
McCants, Will. 2015. The ISIS Apocalypse: The History, Strategy and Doomsday Vision of the Islamic State. New York: St Martin's Press.

McConaghy, Kieran. 2017. Terrorism and the State: Intra-State Dynamics and the Response to Non-State Political Violence. Basingstoke: Palgrave Macmillan.

McMaster, H. R. 1997. Dereliction of Duty: Lyndon Johnson, Robert McNamara, the Joint Chiefs of Staff, and the Lies that Led to Vietnam. New York: HarperCollins.

Matchett, William. 2016. Secret Victory: The Intelligence War that Beat the IRA. Lisburn: Hiskey Ltd.

Mueller, John and Stewart, M. G. 2016. Chasing Ghosts: The Policing of Terrorism. Oxford: Oxford University Press.

Omand, David. 2010. Securing the State. London: Hurst.

O’Mara, Shane. 2015. Why Torture Doesn't Work: The Neuroscience of Interrogation. Cambridge: Harvard University Press.

Ranstorp, Magnus. 2009. "Mapping Terrorism Studies After 9/11: An Academic Field of Old Problems and New Prospects." In Critical Terrorism Studies: A New Research Agenda, edited by Richard Jackson, Marie Breen-Smyth and Jeroen Gunning, 13-33. London: Routledge.

Richardson, Louise. 2006. What Terrorists Want: Understanding the Terrorist Threat. London: John Murray.

Roberts, Adam. 2015. “Terrorism Research: Past, Present, and Future.” Studies in Conflict and Terrorism 38 (1): 62-74. doi: 10.1080/1057610X.2014.976011.

Sageman, Marc. 2017. Misunderstanding Terrorism. Philadelphia: University of Pennsylvania Press.

Schiemann, J. W. 2016. Does Torture Work?. Oxford: Oxford University Press. 
Silke, Andrew. 2007. "The Impact of 9/11 on Research on Terrorism." In Mapping Terrorism Research: State of the Art, Gaps and Future Direction, edited by Magnus Ranstorp, 76-93. London: Routledge.

Stern, Jessica and Berger, J. M. 2015. ISIS: The State of Terror. London: William Collins.

Stohl, Michael. 2008. "Old Myths, New Fantasies and the Enduring Realities of Terrorism." Critical Studies on Terrorism 1 (1): 5-16. doi: 10.1080/ 17539150701846443.

Toobin, Jeffrey. 2017. American Heiress: The Kidnapping, Crimes and Trial of Patty Hearst. London: Profile.

Warsi, Sayeeda. 2017. The Enemy Within: A Tale of Muslim Britain. London: Allen Lane.

Weiss, Michael and Hassan, Hassan. 2015. ISIS: Inside the Army of Terror. New York: Regan Arts.

Williams, B. G. 2017. Counter Jihad: America's Military Experience in Afghanistan, Iraq, and Syria. Philadelphia: University of Pennsylvania Press.

Whitfield, Teresa. 2014. Endgame for ETA: Elusive Peace in the Basque Country. London: Hurst. 


\section{Biographical Note}

Richard English is Professor of Politics at Queen's University Belfast, where he is also Distinguished Professorial Fellow in the Senator George J. Mitchell Institute for Global Peace, Security and Justice. He is the author of eight books, including the award-winning studies Armed Struggle: The History of the IRA (2003) and Irish Freedom: The History of Nationalism in Ireland (2006). His most recent book, Does Terrorism Work? A History, was published in 2016 by Oxford University Press. He is a Fellow of the British Academy, a Member of the Royal Irish Academy, a Fellow of the Royal Society of Edinburgh, a Fellow of the Royal Historical Society, an Honorary Fellow of Keble College Oxford, and an Honorary Professor at the University of St Andrews. 